\title{
EDUCATIONAL POLICY BORROWING IN THE CAMEROONIAN HIGHER EDUCATION SYSTEM: A DEBATABLE PARADIGM FROM STAKEHOLDERS' PERSPECTIVES
}

\author{
Elizabeth Agbor Eta ${ }^{1}$ \\ University of Turku, Finland
}

\section{Joyce Afuh Vuban}

University of York, UK

\begin{abstract}
Educational policy borrowing is almost the norm in today's policy making, partly because of globalisation, the rise in information and communication technology, and the involvement of external stakeholders in higher education governance. However, the reasons, applications, and results obtained from the adoption and implementation of borrowed policies may result in debates among educational stakeholders because of varying perspectives across contexts, and across individuals. This article discusses, from a general perspective, the perspectives of higher education stakeholders in Cameroon towards policy borrowing; and analyses a specific case of policy borrowing via the adoption and implementation of Bologna Process ideas in this context. The findings discussed in this paper, both from the general standpoint and in terms of this specific case, indicate that policy borrowing is a controversial phenomenon in Cameroon's higher education system. Although our contribution in this article is to the analytical strand of policy borrowing as a phenomenon, this article nonetheless has implications for the normative approach, considering that policy borrowing as a practice is part and parcel of today's policy making.
\end{abstract}

Keywords: Educational Policy Borrowing, Cameroon, Higher Education, Stakeholders

\section{Introduction}

Although the authority to develop national policies, including educational policies, is the responsibility of national governments, globalisation, the rise in information and communication technology (Perry \& Tor, 2009; Rizvi \& Lingard, 2010), and the increasing involvement of external stakeholders in higher education governance (Ball, 2012, Chow \& Ravinet, 2015) have upset the nature of this authority. These factors contribute to increased

${ }^{1}$ Correspondence: Department of Education, Assistentinkatu 5, 20014 Turku, Finland; Email: eaoroc@utu.fi 
access, exposure, interaction (Perry \& Tor, 2009), and movement of people, ideas, policies, and practices from elsewhere, which find their way into national policy discourse and/or practices. These are referred to in policy studies as policy transfer.

Policy transfer is 'a process by which knowledge of policies, administrative arrangements, institutions, and ideas in one political system (past or present) is used in the development of policies, administrative arrangements, institutions and ideas in another political system' (Dolowitz \& Marsh, 2000, 5). This definition of policy transfer indicates that there are at least two contexts involved in the process. On the one hand, there is the context from where the policy originates (lending country) and on the other hand, the context receiving the policy (borrowing country) (Waldow, 2012). Both contexts are needed for policy transfer to occur. In other words, policy transfer constitutes lending and borrowing (Waldow, 2012). However, our focus in this article is on the latter context (the receiving country), using the case of Cameroon.

This article is grounded in the argument that in today's national (education) policy making, policy borrowing is the norm and not an exception (Steiner-Khamsi, 2013). Phillips and Ochs (2004, p. 774) define policy borrowing as a 'conscious adoption in one context of policy observed in another'. This indicates the interest policy makers have in policies and practices from elsewhere (lending context), informed by myriad reasons. However, the reasons, applications, and results obtained from the adoption and implementation of borrowed policies may result in debates among educational stakeholders because of varying perspectives across contexts, and across individuals. Our focus in this article is to explore policy borrowing as a concept (from a general perspective) in the Cameroonian higher education system, and to illustrate a practical and recent example of policy borrowing Bologna Process adoption and implementation.

The Bologna Process is a European intergovernmental initiative that created the European higher education area (EHEA) with the objective of achieving 'greater compatibility and comparability of the systems of $\mathrm{HE}$ ', increase 'the international competitiveness of the European system of HE' as well as its 'world-wide degree of attraction' (Bologna Declaration, 1999). The process started in 1998 with the signing of the Sorbonne Declaration by the education ministers of France, Italy, Germany, and the United Kingdom. The number of signatory countries increased to 29 in 1999 with the signing of the Bologna Declaration. Currently, 48 European countries are signatory to the process, all of which have pledged their commitment to implementing Bologna objectives in their systems, including: a system of easily readable and comparable degrees, a system based on three cycles, and a common system of credits to promote citizens' mobility and employability.

Although originally conceived as a solution to the challenges facing European educational systems, the Bologna Process has influenced reforms in Africa generally and Cameroon particularly. Implementation of Bologna objectives in the Cameroonian higher education system started in the 2007/2008 academic year, following the adoption of these objectives by the heads of state of the Economic and Monetary Community of Central Africa (CEMAC) as the 'Licence-Master-Doctorat' (LMD) reform (Eta, 2015; Eta \& Vubu, 2016, Eta \& Vuban, 2017). The LMD aimed to establish the CEMAC Space for Higher Education Research and Professional Training to promote student and staff mobility; facilitate certificate equivalences; harmonise study programmes, qualifications, and awards; enhance the attractiveness of higher education in the sub-region; and integrate graduates into the regional and global labour market (Libreville Declaration, 2005). These goals were to be achieved through (1) the adoption of a system where certificates are readable and comparable at the national, sub-regional, and international levels; (2) a system with two programmes: 
undergraduate and post-graduate with three degrees involved - bachelor's, master's, and doctorate degrees; (3) a system of credit; and (4) professionalisation of educational programmes (CEMAC Council of Ministers, 2006).

This article has two objectives:

1. to examine the perceptions of different higher education stakeholders on policy borrowing in the Cameroonian higher education as a general phenomenon and;

2. to analyse the adoption and implementation of Bologna Process objectives in the Cameroonian higher system as a case of policy borrowing.

We begin the article with a discussion on policy borrowing at the conceptual level. Next, we examine stakeholders' perspectives of policy borrowing in the Cameroonian higher education system, broadly speaking, in a bid to identify the factors that influence policy borrowing in this context, while also examining points of disagreement regarding these factors. Finally, we discuss Bologna Process adoption and implementation in Cameroon as a practical example of policy borrowing. The article argues that policy borrowing is a controversial phenomenon in Cameroon's higher education system.

\section{Current Debates and Perspectives on Educational Policy Borrowing}

There is the recognition in the literature that similar educational reforms are spreading around the world, and the question is whether policy borrowing has increased because of globalisation (Steiner-Khamsi \& Waldow, 2012). This question has at least two implications. First, that globalisation is only a contributing factor to the flow of similar ideas worldwide and second, that educational policy borrowing, as a phenomenon, is not new. As a fundamental theme in comparative education research, educational policy borrowing can be traced to the 1880s, with the 1817 publication of Marc-Antione Jullien's work 'Esquisse d'un ouvrage sur l'éducation comparế' (Plan for a Work on Comparative Education) (Beech, 2006; Bray, 2007; Fan, 2007; Phillips, 1989, 2005). Jullien's work emphasised the need to identify best practices and useful lessons in other systems (Bray 2007; Phillips, 1989) with the main driving factor being the "desire to "borrow" ideas that might be successfully imported into the home system’ (Phillips, 2005, 23).

Early comparativists, such as Victor Cousin, proposed a three-step borrowing process - 'first, to study local problems and needs in a particular educational system; second, to search for educational systems that had resolved similar problems and faced similar needs; and finally, to recommend borrowing of solutions from these educational systems' (SteinerKhamsi, 2002, p. 58). Similarly, Phillips and Ochs (2003, 2004), based on their study of the British interest towards the German educational system over a period of two hundred years, developed a four-stage model of policy borrowing, including the cross-national attraction stage, the decision stage, the implementation stage, and the internalisation/indigenisation stage. According to their model, the cross-national attraction stage emphasises the impulses (local need) that sparked borrowing. These processes indicate that finding solutions to the local problem with the objective of improving educational provisions at home was the reason for policy borrowing (Dolowitz \& Marsh, 2000; Phillips \& Ochs 2004; Steiner-Khamsi, 2004). It also implies that educational borrowing was viewed as a rational process, in which alternative solutions to the local problem were sought and the best alter native selected (Rui, 2007).

However, current research indicates that besides the need to solve a local problem, there are political and economic reasons behind policy borrowing. The political reasons are associated with the international standard motive (Steiner-Khamsi, 2014) used by global players to impose 'supposed' best practices on national governments, and to monitor 
developments at the national level (Steiner-Khamsi, 2012). The international standard 'card' is 'played' by local governments to give authority to reforms at home and to legitimise contested or controversial domestic reforms (Steiner-Khamsi, 2002; Halpin \& Troyna, 1995; Ochs, 2006; Dolowitz \& Marsh, 2000). It is also used to push reforms by national governments because of the fear of being left behind (Steiner-Khamsi \& Stolpe, 2006) and the desire to gain legitimacy at the international level (Fulge et al., 2016). Thus, international standard rationale for policy borrowing is used in varied ways; 'to generate reform pressure' and as 'a catalyst for change' despite the lack of consensus on its meaning, and 'they serve as empty vessels that are, whenever needed, filled with local meanings' (Steiner-Khamsi, 2016, 383-4). According to the literature, the above-mentioned reasons for policy borrowing cut across both developed and developing countries.

Contrarily, the economic agenda pushing policy borrowing, referred to as the 'economics of policy borrowing', is common with developing countries where adoption is a 'precondition for receiving aid' (Steiner-Khamsi 2013, 156) from donor agencies and international organisations (Dolowitz and Marsh, 2000; Perry and Tor, 2009). Borrowing that occurs because of aid conditionality is coercive in nature, as national governments are compelled to adopt because of the funding (money) associated with adoption. As SteinerKhamsi (2013) observed, implementation of such policies may only run for the duration and availability of the external funding (Steiner-Khamsi, 2013). Numerous examples abound illustrating the role of donor involvement in shaping policy adoption in Africa, where 'most new projects in education and a portion of recurrent expenditure rely on externally provided funding' (Samoff, 1994, p. 143). For example, Spreen (2004) illustrates how local experts in 1994 post-apartheid South Africa had funding from bilateral donor organisations and adopted various models of outcome-based education, which had been implemented in Australia, New Zealand, the United States, and Canada. Similarly, Chisholm and Leyendecker (2008) examine curricular reforms (specifically learner-centredness, outcome- and competency-based education, and national qualifications frameworks) in sub-Saharan Africa and illustrate how these reforms were supported by multilateral organisations as the pedagogical ideal for facilitating change. According to Sall and Ndjaye (2007), France has also influenced Bologna adoption in Africa, especially in its formal colonies, by providing financial support.

The myriad reasons for policy borrowing have also led to debates about what constitutes borrowing and how it occurs. For example, the economics and politics associated with policy borrowing have contributed to the expansion of the term's definition, from concrete lessons learnt from an educational system to suggesting that 'all global reforms' or 'traveling policies' (Steiner-Khamsi, 2012, p. 11) qualify as policy borrowing. In the case where borrowing occurs for political or economic reasons, instead of the borrowing process starting from the identification of the local problem (Eta, 2018), as Steiner-Khamsi (2013) notes, the tendency is for the global solution to first be adopted before the problem's identification, in order to fit the existing global solution.

In addition, because of harmonisation tendencies, educational policies are increasingly being adopted first at the international or regional levels by international organisations or regional actors before being transferred to the national level, which also qualifies as policy borrowing (Steiner-Khamsi, 2012). A case in point is the Bologna Process, which aims to harmonise European systems of education. The involvement of these external stakeholders in higher education governance, by implication, means that policy borrowing also occurs as part of national governments' obligation to international/regional agreements (Dolowitz \& Marsh, 2000; Steiner-Khamsi, 2012, Eta, 2018). From this perspective, policy borrowing 
occurs because of the need to conform and converge with global educational initiatives (Ochs, 2006).

According to Steiner-Khamsi (2014, 2016), educational borrowing research can be divided into two strands, normative and analytical. On the one hand, studies that take a normative approach aim at identifying best practices that can be transferred from one system to another (Steiner-Khamsi, 2016). On the other hand, analytical studies aim at understanding the why and how policy borrowing occurs, and the impact borrowed policies may have on existing practices (Steiner-Khamsi, 2016). Although both strands are important, in this study, our focus is on the analytical strand, examining why policy borrowing occurs in the Cameroonian higher education system, bringing out arguments both for and against policy borrowing from a general standpoint, and using Cameroon's implementation of Bologna principle to illustrate a case of policy borrowing.

\section{Methodology}

Although policy borrowing is an underlining concept in the works of both authors, there is a fundamental difference in their focus as captured in the aims of this paper. The first goal of this article is to explore the perspectives on policy borrowing. The focus of the second author's research is on policy borrowing from a general perspective to highlight the factors, problems, and impacts of policy borrowing on the Cameroonian higher education system using the Bologna Process as an example of a borrowed policy for illustration. Data for this study was collected in 2015 between October and December. With regards to methodology, the study employed the qualitative research design with 56 interviews and two focus group discussions comprising four participants each. The participants were students, lecturers, and university officials from the Universities of Bamenda, Buea and Yaoundé 1; St Monica University-The American International University; Bamenda University of Science and Technology; Cameroon Christian University; Catholic University of Cameroon; and Catholic University of Central Africa. Interviews were also conducted with officials from Cameroon's Ministry of Higher Education and multinationals including officials from the Commonwealth, African Development Bank, and L'Agence Universitaire de la Francophonie.

The second goal of this article is to explore Bologna adoption and implementation in Cameroonian higher education using policy borrowing as a theoretical framework in this context (focus of the first author's research). Amongst existing higher education policies and reforms in Cameroon today, the Bologna Process is perceived as the most prominent and explicit borrowed policy in the country (Vuban, Unpublished manuscript). In addressing the second aim of this paper, evidence was drawn from already published articles by the authors and other co-authors. These published works focus on different aspects of Bologna Process adoption and implementation in the Cameroonian higher education system, while leaning on policy borrowing for theoretical backing with topics ranging from: the justifications for the adoption of Bologna Process in Cameroon (Eta, 2015); transfer and reception of Bologna Process ideas in the Cameroonian higher education system (Eta, Kallo \& Rinne, 2017); adaptation of Bologna Process degree structure and credit system at universities in Cameroon (Eta \& Vubo, 2016); and the challenges of Bologna Process implementation in Cameroon (Eta $\&$ Vuban, 2017). The use of these already published articles is not for repetition; rather, the articles are research materials illustrating the controversial nature of The Bologna Process adoption and implementation in Cameroon.

\section{Perceptions of Educational Policy Borrowing in Cameroon Policy borrowing and poverty/aid conditionality}


Cameroon is one of the 37 developing countries classified as a heavily indebted poor country (HIPC), eligible for assistance from the International Monetary Fund and the World Bank because of high levels poverty and debt overhang. The HIPC is an initiative aimed at providing debt relief and low interest loans on the condition that national governments undertake a range of reforms, including educational reforms. Besides the HIPC initiative, undertaking reforms conceived and designed elsewhere, or introducing already existing solutions that have worked elsewhere, are common conditions for receiving aid in developing countries, Cameroon included. Thus, poverty was viewed as a contributing factor to policy borrowing in Cameroon:

We do not have enough capital. The fiscal policies of our government are very stringent, and our tax base is very, very narrow... So, in order to generate more income, we have to align ourselves to the policies of foreign donors. That is why I say we have now become enslaved because of finance. (University Official/Lecturer-A, UCAC, 2015)

Policy borrowing as a condition for receiving aid in Cameroon ties with most interviewees' perception that 'he who pays the piper dictates the tune' of the money. This is because those who come up with these HE policies also associate the policies with money, hence facilitating the adoption and implementation of borrowed or western ideas/policies in Cameroon, irrespective of whether these policies reflect Cameroonian realities or needs.

However, policy borrowing because of aid conditionality, especially from multinationals, was said to have a negative impact on the system, especially with regards to staff working conditions as per low salaries in Cameroonian higher education. Thus, an official recount that:

The staff of Cameroon are the poorest paid, I am sure, in the whole world... When we went out for strike in the University of Buea that we wanted a salary increase at least to measure up with Senegal, as we took Senegal as a measure for comparison which was the lowest paid apart from Cameroon during that period, what they instead gave us was Research Modernization Grant which is now being paid once in every three months. We have asked them to put it in our salaries and they say if they do so IMF [International Monetary Fund] will not be happy that they are increasing salaries in Cameroon...According to them, when you are in the red zone and not economically buoyant, you should not be taking up salaries. (University Official/Lecturer-F: UBa: 2015)

In this regard, policy borrowing was perceived as detrimental to the system because it negatively impacts the individuals therein. The low salaries contribute not only to poor working conditions for university lecturers but are perceived as a 'bad academic condition' imposed by multinationals as a condition for funding. This policy has devastating consequences such as low motivation for teachers and poor student-teacher relationships; by encouraging less assiduity, this policy also leads to poor quality education (Vuban, unpublished manuscript).

\section{Policy borrowing for development}


The quest for development was identified as a central factor influencing policy borrowing in the Cameroonian higher education system. Participants based this argument on the idea that Cameroon is an under-developed country, co-existing among developed countries. The tendency has therefore been for Cameroon to implement some of the higher education policies and reforms from developed countries in its own system because of the aspiration to one day reach the same level of development as these other countries, where investment in education is highly valued. This vision, according to interviewees, is facilitated by borrowing policies and practices from developed countries that will assist in laying a good foundation on which development will follow:

For now, the level of our development drives the need for us to learn. We have not yet stabilised our foundation. If this foundation is stabilised, we can start building something. We can start thinking of what is really Cameroonian and start building something. We need a good foundation and before we build that foundation we need borrowed ideas... We need borrowed ideas to lay a foundation on which we can lean. (University Official/Lecturer-E, CCU: 2015).

Interviewees noted that when there are international conferences, for example, the meeting of Central African heads of state, amongst their discussions have been issues of university reform. There are also meetings of ministers of education in Africa and during such meetings, experts from UNESCO, the World Bank and other organisations are always present to discuss using higher education as a driver for economic development. This is because, as interviewees noted, one cannot separate education from economic development. Hence, ideas that have proven to work elsewhere are borrowed and inculcated in Cameroon, geared at improving Cameroon's economy through its higher education. An example of such policies, participants noted, is the recent focus on increasing higher education's relevance (especially in universities) to the society and labour market through professionalisation of university courses, programmes, and extra-curricular activities.

However, the idea of development having accelerated policy borrowing in the Cameroonian higher education system has been criticised. For some interviewees, development, particularly in the area of higher education, has long been restricted by multinationals:

In the late 70s and 80s, the World Bank was against the development of higher education. It hurt higher education in this country arguing that investments at lower levels of schooling yield more dividends or returns than investments in higher education. The same World Bank regretted afterwards and admitted that it has hurt the development of higher education in this country. (University Official-A; UB: 2015)

Thus, such policies of multinationals were seen as one of the reasons for the country's very slow development. As interviewees argued, multinationals focused on funding primary education to improve literacy rates at a lower cost than spending on higher education. These multinationals at the time, according to interviewees, failed to consider that the development of Cameroon, like any other country, lies in the quality and size of its workforce. Higher education plays this fundamental role due to its professional, entrepreneurial, and researchbased training skills, which it imparts on university students; no nation can develop based on 
mere numeracy or literary skills, which are the main goals of primary education (Vuban, unpublished). Stakeholders also argued that the restrictions multinationals have placed on higher education still have a negative impact on its place in the national developmental agenda to date:

At first, there was a tendency for people to think that higher education does not serve any purpose in a third world country or in an African country. That has been a very wrong notion particularly from our European partners and world organizations... A country cannot develop in any way without higher education and that is why we were surprised to see that when the Growth and Employment Strategy Paper was created, and we did not see the place of higher education in it, many people questioned it. The minister [of higher education] was the first person to question it. (University Official-C; UB: 2015).

\section{Policy borrowing and colonialism}

Policy borrowing was identified as one of the models through which foreign practices get inculcated in the higher education system through Cameroon's historical affiliation with ex-colonialists. Borrowing elements from the colonial systems was inevitable, because as most interviewees noted, 'We are a young nation. Our universities are still young'. The higher education system of ex-colonialists is already well developed, thus serving as a model to replicate in Cameroon:

Cameroon has a type of policy that when you look at just its structures they are just like those in France. We just like to borrow, copy and paste without trying to look at possibilities of adapting it to suit our own environment. I would think there is a heavy dose of borrowing and mostly from France. (University Official/Lecturer-E: 2015)

Higher education started in Cameroon in 1961 with the creation of a university centre that was transformed into a full-fledged university in 1962. The university was constructed with assistance from the French government and modelled after the French tradition in terms of organisational arrangements and structure. The degree structure in this university followed the multiplicity of degrees such as 'Diplôme d'études Générales' (DEUG), 'Licence', 'Maîtrise', 'Diplôme d'études approfondies' (DEA), 'Doctorat de troisième cycle' and 'Doctorat d'État', offered in France. During the 1993 university reforms in Cameroon, an Anglo-Saxon system was created.

The creation of the Anglo-Saxon university alongside other French-modelled universities indicates that Cameroon's higher education borrows aspects from both its colonialists, France and Britain, and not only France as the above quotation states. Contrary to the French-modelled university, the Anglo-Saxon university operated on the Bachelor's, Master's and Doctoral degree structure. According to Eta (2018), borrowing from the AngloSaxon tradition and creating an Anglo-Saxon model university in Cameroon was a way to preserve the dual cultural legacy of Cameroon. Thus, according to interviewees in this study, in as much as France and Britain remain the yardstick, they will always influence higher education policy in Cameroon.

Notwithstanding, it was also argued that policy borrowing based on colonial ties has encouraged the negligence of the African/Cameroonian cultural identity: 
Right now, you and I are speaking in English. Why can't we speak in Mungaka or in Wimbum or in Kedjom? At the end of the day, to me there is this frustration that I have to depend on a colonial power's language for my livelihood... I remember the last time I travelled using Kenyan Airways ... the hostess welcomed us in Swahili before English. How I dream of a day when I enter Cameroon Airlines and be welcomed in one Cameroonian language before French or English. Last month when I was coming back from the US, the pilot was struggling to say 'Mbana eyeh', welcoming us to Cameroon in Douala. Instead, most of us were laughing but I found it very frustrating... Some Cameroonians found it funny but didn't look at the impact of it. This means that a French man [the pilot] is telling us that our national language is important, but we didn't see it that way. This is something wrong! These are things that higher education should address. (University Official-B; UYI: 2015).

Apart from the negligence of the African/Cameroonian cultural identity, policy borrowing via the lens of colonialism has also been argued as being one of the leading causes of unemployment in Cameroon. Teaching English and French in combination with other subjects are the basis of classical training in Cameroonian higher education, which undermines employability and entrepreneurship, leading to high rates of unemployment and external inefficiency of the higher education system. Instead of focusing on colonial languages, participants argued for the need to foster local practices:

Like our traditional customary rules, we have a lot that we can borrow from this local people that will help to push our universities. We have a lot of customary practices which we could enhance that will permit us to live in harmony with our society more than implementing foreign policies. (University Official-B, UBa, 2015)

\section{Policy borrowing, the role of globalisation and the need for uniformity and comparability}

Interviewees saw globalisation as having influenced policy borrowing in higher education in Cameroon because of the need to be up-to-date with what exists in other parts of the world:

In a globalised world today, we borrow a little from each country which we think can be suited to our own realities. (Commonwealth Official-F, 2015)

With globalisation, Cameroonians need to know what is happening in other countries and train its citizens to adapt in other cultures or the global knowledge economy, which will enable its higher education graduates to seek work not only within Cameroon but across the globe as 'world citizens'. For Cameroonians graduates to effectively compete in the global knowledge economy, interviewees highlighted that Cameroonian higher education must align its training and place its graduates at the same standard with universities across the globe. This was explained in terms of the quest for functional knowledge for scholars to fit in a globalised world: 
For example, the PhD students that I am training should be like those trained in York. Yes! Why not? If I really want to have good PhD students, I cannot do it alone because the poor scholars will be limited when exposed to international conferences. They will realize that they have not covered or mastered much and may have to go back to the roots of their training to master knowledge. I think this is the real essence of borrowing ...so that we can also produce people with the same know-how. (University Official-C, SMU, 2015)

Besides the need to align with the global knowledge economy, policy borrowing was also perceived as indispensable because of the need to be like universities in the west:

In terms of Cameroonian state universities which I am familiar with; and the American and UK systems which we are borrowing from; I think that we have similarities because these are universities which are older in terms of civilization and advancement. We are trying to pattern our universities along the lines of universities in UK and America. (University Lecturer-A, UBa \& $\mathrm{UB}, 2015)$

From a systemic perspective, policy borrowing has been practiced for comparability with other systems and to improve or develop the Cameroonian higher education system and its reforms/policies:

I cannot say that policies have been developed only from a Cameroonian perspective, but I think to get a good system, we had to compare with other systems out of the country to build and improve on our own system...As I earlier said, we cannot work only from one system; that is our own system. We had to compare with what is done elsewhere to have a better and more developed system. (University Official-G, UBa: 2015)

Focusing on contributing to the global knowledge economy and becoming comparable to foreign systems, some stakeholders, however, argued against such notions, especially because of mismatches that always exist between educational content and context:

The content of education automatically does not really fit the context because the foreign policies are most often proposed by people who might have no awareness of the reality of the field but are at the service of the foreign masters who are training them for specific purposes including that of uniformization of the world. (Lecturer-A; UBa: 2015)

The above quotation indicates that there might be a hidden political agenda to instituting global uniformity, with Cameroon via its higher education system as a scapegoat (Vuban, unpublished manuscript).

\section{Policy borrowing and adaptation}

Although comparability is one of the reasons for policy borrowing, according to interviewees, policy borrowing is also supported because of its potential to be locally adapted. Adaptation to local reality is important because the country borrowing is always different from the lending country: 
Of course, every country has borrowed in one way or the other, but the most essential thing is when we borrow we have to make it realistic in our own national terrain. We don't just transport and implant things in our national terrain. When we borrow, we take aspects which can fit in our country and leave out others...it is about borrowing what we think can fit in our system... So, we cannot borrow without making amendments. (Commonwealth OfficialA, 2015)

Based on the experiences of some interviewees, higher education policies in Cameroon have been borrowed mostly from Europe, implemented in the system, and adjusted to respond to the Cameroonian society. However, other participants advocated that HE reforms and policies in Cameroon are not just taken from Europe but the West in general:

These reforms and policies were adopted because given that university education is taken from the western world, the government tries to adapt it to our local context. We take from the west and adapt in our local context...I will give you a blunt and flat answer. The university is a western world concept. So, tell me which policy here that has not been copied from the western world! (University Official-B, UOY-I, 2015).

Interviewees add that whatever learning techniques or teaching methodologies the Cameroonian system borrows, it learns from these systems and in the process of adoption always adds a local touch. At Christian universities, for example, though students are provided with the same technical skills as students from other state universities, they are also taught the church's values or the Christian faith, geared at contributing to nation building, holistic development of individuals, and character formation. This enables students to perform better after leaving school. Therefore, with every borrowing, there is localisation and/or adaptation to context.

According to some stakeholders, however, as much as there are efforts to locally adapt borrowed policies, there is still an adaptation crisis because most policies are seen as 'copy and paste':

But the problem is that we do a copy and paste system and we don't analyse the terrain or take into consideration the people who are going to be part of the system or are undergoing the system. This means that we instead add onto our problems. (University Official-B; UCAC: 2015)

The advent of the internet and lack of other educational resources, according to stakeholders, is what has encouraged the 'copy and paste' syndrome with devastating consequences to research and instruction. For example, the recent shift from teacher-centred to studentcentred learning has unintended consequences for adaptation because of the lack of other educational resources:

I think with the absence of a good library, the internet has rather encouraged plagiarism because the students want to go very fast, so they copy from the internet and the teachers do not have the necessary tools to be able to verify whether these students have copied. (University Lecturer-A; UCAC: 2015) 
It was thus argued that students do not have adequate educational resources to engage in independent and self-paced learning. Because of the lack of learning resources, coupled with financial hardship, the best alternative has been plagiarism or 'copy and paste', which is not only a serious academic misconduct but does not aid in knowledge advancement (Vuban, unpublished manuscript).

\section{Policy Borrowing in Practice: Perceptions of the Bologna Process in Cameroon}

As noted earlier, Cameroon started implementing Bologna Process principles in its higher education system in the 2007/2008 academic year as the LMD in Francophone universities and as BMP in the Anglo-Saxon universities. This section reviews already published works to highlight the different perspectives about its Bologna adoption and implementation in Cameroon.

\section{Perspectives on Bologna Adoption in Cameroon}

From the review, adoption and implementation of Bologna objectives in Cameroon were attributed to the need to meet international standards and for international acceptance of degree, to align with a global trend, to resolve higher education challenges, including the need to harmonise the dual French and Anglo-Saxon systems of education in the country, and to comply with CEMAC's vision to create the CEMAC space for higher education and research (Eta 2015; Eta, Kallo \& Rinne, 2017). Notwithstanding, the reasons Cameroon adopted the Bologna principles, whether the adoption was imposed or voluntary (Eta, Kallo, \& Risto, 2017), seem to be debatable. According to these authors, there were three different perspectives on the adoption. The first postulates that Cameroon's adoption of the Bologna Process/LMD, together with other CEMAC countries, was 'imposed or at least influenced by France' (p. 12). This perspective was based on the title 'LMD' through which these Bologna Principles were adopted in the CEMAC and introduced in Cameroon, as it was under the same title that Bologna reforms were introduced in France. In addition, the perspective that France had influenced such adoption in Cameroon was also based on the ideas that mainly 'French experts had visited universities in Cameroon to talk about the Bologna Process (regardless of whether these experts came from Belgium or France)' (p. 13). However, the above-mentioned study also drew attention to the fact that such an influence might not have been from France, but this assumption was made because CEMAC is comprised mostly of French-speaking countries with a long colonial history.

The second perspective was that the adoption was voluntary; used to resolve higher education challenges in Cameroon, such as the harmonisation of the dual French and AngloSaxon systems of education; to enhance mobility and graduate employability (Eta 2015; Eta, Kallo, \& Rinne, 2017); to foster collaboration with European countries; and to align with a global trend (Eta, Kallo, \& Rinne, 2017). The question of whether Cameroon's adoption of Bologna Principles was voluntary or imposed was controversial, according to Eta, Kallo, and Rinne (2017), because the adoption was based on a political decision, adopted by the head of state (without the involvement of the higher education community), and imposed on the universities. Thus, because of the latter's non-involvement, ideas about the adoption of the Bologna Process in Cameroon were based on interviewees' assumptions.

Another point of debate concerning adoption, according to Eta, Kallo, and Rinne (2017, p. 14), concerns the 'legitimacy of the experts' who led talks about the LMD in Cameroon, 'whether Cameroonians or internationals - and of the country from which lessons were drawn'. From the study carried out by Eta, Kallo, and Rinne (2017), there is the idea 
that the Bologna Process was acknowledged as an Anglo-Saxon model, and some of the objectives had long been practiced in the US, the UK, Nigeria, and the Anglo-Saxon subsystem of education in Cameroon before its adoption of higher education practices from Europe. From this standpoint, therefore, these authors noted that Anglo-Saxon interviewees considered Cameroonians who had studied in France or experts who came from France unqualified to talk about the LMD because they had limited knowledge or understanding of the LMD system' (p. 14).

Instead, the argument was that rather than learning from France, lessons should have been drawn from Nigeria or the Anglo-Saxon university in Cameroon. Given that Cameroon runs a dual system of education with different operational models, the ideas that lessons were drawn from France, and the approaches proposed at the Cameroonian national level were French-inspired, were considered an attempt to 'assimilate the Anglo-Saxon model of education' (p. 15). The impression one gets from reading this article is that this argument was one-sided, as there were no indications of the opinions of Francophones from the Frenchinspired universities about the legitimacy of where lessons were drawn. Therefore, further research on this issue is needed to give a balanced picture of the argument.

\section{Perceptions on the Adaptation and Implementation of Bologna Objectives in Cameroon}

Adaptation is a fundamental aspect of policy borrowing that focuses on how borrowed ideas are modified and re-contextualised to fit the local reality of the borrowing country. One of the reasons attributed to Cameroon's adoption of the Bologna Process is the need to harmonise Cameroon's dual systems of education, especially with regards to the degree structure and the credit system in order to increase mobility within the sub-systems (Eta 2015, Eta, Kallo, \& Rinne, 2017). However, according to Eta, Kallo, and Rinne (2017) there was skepticism of the adapted version, that despite Cameroon's dual system, the adaptation was more in line with practices of the French-inspired universities prior to Bologna adoption in Cameroon. For example, besides making provisions for universities to issue the DEUG and the Maîtrise (intermediate degrees that were meant to be eliminated with the adoption), the master's degree was divided into Master I and Master II as indicated in the Ministry of Higher Education's 2007 text, which according to interviewees, represented the Maîtrise and the DEA in the former French-inspired universities, This text also made an allowance for the credit system that gave room for 'compensation', as was the case with the module and average system practiced earlier in the French-inspired universities (Eta, Kallo, \& Rinne 2017; Eta \& Vubo, 2016).

However, Eta and Vubo (2016) examination of Cameroon's adaptation of the degree structure and credit systems in the dual French and Anglo-Saxon systems of education revealed that universities from both sub-systems implemented them differently. For example, the French-inspired universities followed the provisions stipulated in the Ministry of Higher Education text and modified the credit system to incorporate the compensation model, which allows students to earn credits in a module even when they fail some of the courses. The credits are earned if the students score an average mark in all the courses in that model, where the grade of each failed course is not less than seven on 20. On the other hand, the AngloSaxon university updated its earlier practices and each credit was earned separately. While some French-inspired universities eliminated the DEUG and the Maîtrise of the old system, others continued to issue them on request. All the French-inspired universities in the abovementioned study divided the master programme into I and II with two separate points of 
entry, while the Anglo-Saxon university continued to run the master's progamme on a point entry point model.

The way the degree structure and the credit system were conceived in the Ministry of Higher Education text and implemented in the French-inpsired universities opened up debates about issues of adaptation related to policy borrowing. As higlighted by Eta and Vuban (2017, p. 355), such debates emerged from '(mis)understanding and perception of policy borrowing', which to some was thought to be 'a direct cut-and-paste of practices from elsewhere, which will lead to a complete replacement of existing practices'. This implies that adaptataion of Bologna principles was seen as out of place because it showed a lack of competence in those called to manage the system (Eta, Kallo, \& Rinne, 2017) who ended up 'Frenchifying' or 'Francophonising' the Bologna Process (Eta \& Vuban, 2017, p. 356).

Due to the fact that policy borrowing had to take into account the local context, 'wholesale copying' was seen as irrelevant, thus spearheading local adaptation (Eta \& Vuban, 2017, 356). According to Eta and Vubo (2016), contrary to some interviewees, the degree structure and the credit system were delibrately adapted, among other factors, to meet labour market requirements and accommodate unemployed graduates. These authors also indicated that the DEUG was maintained because it was 'an indication to employers that a student has had some training beyond high school'; while the Maîtrise was also retained because it was a qualification required for the competitive entrance examination into some professional schools (Eta \& Vubo, 2016, 157).

\section{Conclusion}

This paper had two objectives: from a general perspective, to examine the opinions of different higher education stakeholders on policy borrowing in the Cameroonian higher education system, and from a specific standpoint, to analyse the adoption and implementation of Bologna Process objectives in the Cameroonian higher system as a case of policy borrowing. With regards to the first objective, this article dissected educational policy borrowing using different stakeholders' perspectives on carefully identified themes from data collected in 2015, amongst which are poverty/aid conditionality; development; colonialism; globalisation/need for uniformisation/comparability; and adaptation. In examining the second research objective, we relied on already published articles as research material to highlight some debates surrounding the adoption and implementation of such a borrowed model in this context.

The findings presented in this article indicate that policy borrowing as illustrated by stakeholders' argumentative positions presents the phenomenon as a controversial paradigm, as the factors perceived to have influenced policy borrowing in Cameroon were presented as the same factors that have negatively impacted higher education. Similarly, in terms of the 'adoption' of Bologna objectives in Cameroon, findings portray that there has been a controversy about whether the adoption was voluntary or imposed, and the legitimacy of where lessons of the Bologna Process were drawn in Cameroon has also been debatable. This study shows that such controversy might have emerged because of the lack of involvement of higher education stakeholders in the adoption process (Eta, Kallo, \& Rinne, 2017). The implementation of these Bologna objectives in Cameroon also highlighted another level of controversy because the adopted approaches were perceived to be more in line with practices in the French-inspired universities in Cameroon, despite Cameroon's dual structure. Such controversy led to different methods of implementation in both sub-systems in Cameroon 
and in line with Eta (2018), raising the question of whether harmonisation (as one of the reasons for adoption in Cameroon) of the dual structure through the LMD was possible.

Although our contribution in this article was to analyse policy borrowing as a phenomenon, this article nonetheless has implications for the normative approach, given that whether we advocate for it or not, policy borrowing is part and parcel of today's policy making. We thus suggest that a critical appraisal of the borrowed policies be done whenever decisions to learn from abroad are made - highlighting strengths and weaknesses prior to adoption. Otherwise there is a greater likelihood that a second generation of problems will crop up at the level of implementation with high potential for creating further issues in the system, leading to mismatches. Finally, as presented in this article, because of controversy with regards to whether the adoption of Bologna objectives in Cameroon was imposed or voluntary, there is a need to institute good university governance by reinforcing transparency and participatory decision-making involving different stakeholders, who will also be directly responsible for implementation, in the adoption phase. This may reduce potential areas of controversy and possible resistance once borrowed policies are introduced into the system.

\section{References}

Ball, S. J. (2012). Global Education Inc.: New Policy Networks and the Neoliberal Imaginary. USA \& Canada: Routledge.

Beech, J. (2006). The Theme of Educational Transfer in Comparative Education: a View over Time. Research in Comparative Education, 1(1), 2-13.

Bologna Declaration. (1999). The Bologna Declaration of 19 June 1999. Bologna Secretariat, European Commission. http://www.bolognaberlin2003.de/pdf/bologna-declaration.pdf.

Bray, M. (2007). Actors and Purposes in Comparative Education. In: M. Bray, A. Bob, \& M. Mark (Eds.) Comparative Education Research: Approaches and Methods. (pp. 15-38). Hong Kong: Springer.

CEMAC Council of Ministers. (2006) Directive No. 01/06-UEAC-019-CM-14 Portant application du systémé LMD (Licence, Master, Doctorat) dans les Universités et etablissements d'enseignement supérieur de l'espace CEMAC. Libreville, Gabon.

Chisholm, L \& Ramon L. (2008). Curriculum Reform in Post-1990s Sub-Saharan Africa. International Journal of Educational Development 28 (2): 195-205.

Chou, M-H. \& Ravinet, P. (2015). The Rise of Higher Education Regionalism: An Agenda for Higher Education Research. In J. Huisman, H. de Boer, D. Dill, \& M. SoutoOtero (Eds.), The Palgrave International Handbook of Higher Education Policy and Governance (pp. 361-378). UK: Palgrave Macmillian

Dolowitz, D. P. \& Marsh, D. (2000). Learning from abroad: the role of policy transfer in contemporary policy-making. Governance: An International Journal of Policy and Administration, 13(1), 5-23.

Eta, E. A, Kallo, J, and Rinne, R. (2017). Process of transfer and reception of Bologna Process ideas in the Cameroon higher education system. European Educational Research Journal, DOI: 10.1177/1474904117733376.

Eta, E. A. \& Vuban, J. A. (2017). The Bologna Process in Cameroon: Challenges of reforming the Cameroonian higher education system through Licence-MasterDoctorat reform. In Piot-Lepetit, I. (ed.), Cameroon in the $21^{\text {st }}$ century, challenges and prospects, environments and people (pp. 343-367). New York: Nova Science Publisher. 
Eta, E. A. (2015). Policy Borrowing and Transfer, and Policy Convergence: Justifications for the Adoption of the Bologna Process in the CEMAC region and the Cameroonian Higher Education System through the LMD Reform. Comparative Education, 51(2), 161-178.

Eta, E. A. (2017). Enhancing Graduate Employability in Cameroonian Universities within the Context of the Adoption of the Bologna Process through License-MasterDoctorate Reform. Higher Education Policy, https://doi.org/10.1057/s41307-0 170055-7

Eta, E. A. (2018). Educational policy borrowing: Adoption and adaption of Bologna Process objectives in the Cameroonian higher education system (Doctoral dissertation). University of Turku, University of Turku Press: Turku, Finland).

Eta, E. A., \& Vubo, E.Y. (2016) Global references, local translation: Adaptation of the Bologna Process degree structure and credit system at universities in Cameroon', Globalisation, Societies and Education, 14(4), 492-5 12.

Fan, P. (2007). Educational Policy Borrowing's Past, Present, Future: A Literature Review (Master's thesis). University of Oxford, Oxford, United Kingdom.

Fulge, T., Bieber T., \& Martens, K. (2016). Rational Intentions and Unintended Consequences: on the Interplay between International and National Actors in Education Policy. In: Mundy K, Andy G, Bob L and Antoni V (Eds.), The Handbook of Global Education Policy (pp. 453-469). Oxford: Wiley and Blackwell.

Halpin, D., \& Troyna, B. (1995). The Politics of Educational Policy Borrowing. Comparative Education, 31(3), 303-310.

Libreville Declaration. (2005). Declaration de Libreville sur la construction de l'espace CEMAC de L'enseignment superieur, de la recherche et de la formation professionnelle, Libreville: CEMAC.

Ochs, K. (2006). Cross-national Policy Borrowing and Educational Innovation: Improving Achievement in the London Borough of Barking and Dagenha. Oxford Review of Education 32(5): 599-618.

Perry, L. B. \&Tor, G. (2009). Understanding Educational Transfer: Theoretical Perspective and Conceptual Framework. Prospects 28, 509-526.

Phillips, D. (1989). Neither a Borrower nor a Lender be? The Problems of Cross-National Attraction in Education, Comparative Education, 25(3), 267-274.

Phillips, D. (2005). Policy Borrowing in Education: Framework for Analysis. In J. Zajda (Ed.), International Handbook on Globalisation, Education and Research (pp. 23-34). Netherlands: Springer.

Phillips, D., \& Ochs, k. (2004). Researching Policy Borrowing: Some Methodological Challenges in Comparative Education. British Educational Research Journal, 30(6), 773-784.

Phillips, D., and Ochs K. (2003). Processes of Policy Borrowing in Education: Some explanatory and Analytical Devices. Comparative Education, 39(4), 451-461.

Rizvi, F. \& Lingard, B. (2010). Globalizing Education policy. London, England: Routledge.

Rui, Y. (2007). Comparing Policies. In B. Mark, A, Bob, \& M. Mark (Eds.), Comparative Education Research: Approaches and Methods (pp. 241-262). Springer.

Sall, H. M., \& Ndjaye, B. D. (2008). Higher Education in Africa: Between Perspectives opened by the Bologna Process and the Commodification of Education. European Education, 39(4), 43-57. 
Samoff, J. (1994). Education Policy Formation in Tanzania: Self-Reliance and Dependence. In David, R. E. (ed), Education Policy Formation in Africa: A Comparative Study of Five Countries. Washington: U.S. Agency for International Development, 85-126.

Steiner-Khamsi, G. \& Waldow, F. (Eds.). (2012). Policy Borrowing and Lending in Education. London: Routledge.

Steiner-Khamsi, G. (2002). Re-Framing Educational Borrowing as a Policy Strategy. In M. Caruso (Ed.), Internationalisierung: Semantik und Bildungssystem in Vergleichender Perspektive (pp. 57-89). Frankfurt, Germany: Peter Lang.

Steiner-Khamsi, G. (2004). Globalization in Education: Real or Imagined? In G. SteinerKhamsi (Ed.), The Global Politics of Educational Borrowing and Lending (pp.1-6). New York, NY: Teachers College Press.

Steiner-Khamsi, G. (2006). The Economics of Policy Borrowing and Lending: A Study of Late Adopters. Oxford Review of Education, 37(2), 151-171.

Steiner-Khamsi, G. (2013). What is Wrong with the 'What-Went-Right' Approach in Educational Policy? European Educational Research Journal, 12(1), 20-33.

Steiner-Khamsi, G. (2014). Cross-National Policy Borrowing: Understanding Reception and Translation. Asia Pacific Journal of Education, 34(2), 153-167.

Steiner-Khamsi, G. (2016). New Directions in Policy Borrowing Research. Asia Pacific Education Review, 17: 381-390.

Steiner-Khamsi, G., \& Stolpe, I. (2006). Educational Import: Local Encounters With Global Forces in Mongolia. New York: Palgrave Macmillan.

Vuban, J. A. (unpublished manuscript). Policy Borrowing in Cameroonian Universities: Factors, Problems and Impacts.

Waldow, F. (2012). Standardisation and Legitimacy: Two Central Concepts in Research on Educational Borrowing and Lending. In: G. Steiner-Khamsi \& F. Waldow (Eds.), World Year Book of Education: Policy Borrowing and Lending in Education (411-427). London: Routledge.

\section{About the Authors}

Elizabeth Agbor Eta, PhD, is a project researcher at the Center for Research on Lifelong Learning and Education, University of Turku, Finland. Her doctoral dissertation on the influence of the Bologna Process on the Cameroonian higher education system received the Finnish Educational Research Association's award for the 2018 doctoral dissertation of the year. Her research interest includes: comparative education, global education policies, higher education policy, and research ethics. Her recent publications include: 'Policy borrowing and transfer, and policy convergence: justifications for the adoption of the Bologna Process in the CEMAC region and the Cameroonian higher education system through the LMD reform', (Comparative Education, 2015), 'Enhancing graduate employability in Cameroonian universities through professionalization in the context of the 'License-MasterDoctorat'Reform' (Higher Education Policy, 2017), 'Global references, local translation: adaptation of the Bologna Process degree structure and credit system at universities in Cameroon', co-authored with Emmanuel Yenshu Vubo (Globalisation, Societies and Education, 2016), 'Process of transfer and reception of Bologna Process ideas in the Cameroon higher education system', co-authored with Johanna Kallo and Risto Rinne (European Education Research Journal, 2017), 'Negotiating access to research sites and participants within an African Context: The case of Cameroon' co-authored with Joyce Afuh Vuban (Research Ethics, 2018). 
Joyce Afuh Vuban is holder of a Bachelor's degree in Curriculum Studies and Teaching Biology and a Master's degree in Educational Foundations and Administration from the University of Buea, Cameroon. Joyce is a qualified teacher trainer and also holds a professional teaching diploma called Diplôme de Professeur de l'Enseignement Normal 2eme Grade (DIPEN II). She is an associate Fellow of the Higher Education Academy (AFHEA) in the United Kingdom; and also a doctoral candidate at the York Graduate School, University of York, United Kingdom. 